\title{
Enhanced Performance of PMSG in WECS Using MPPT - Fuzzy Sliding Mode Control
}

\author{
Mohammad Berel Toriki*, Muhammad Khamim Asy’ari, Ali Musyafa’ \\ Engineering Physics Department, Sepuluh Nopember Institute of Technology, Surabaya 60119, Indonesia
}

Corresponding Author Email: mohammad.19023@mhs.its.ac.id

https://doi.org/10.18280/jesa.540110

Received: 3 December 2020

Accepted: 20 January 2021

\section{Keywords:}

wind turbine, fuzzy sliding mode control, boost converter, maximum power point tracking

\begin{abstract}
The wind turbine is a tool used to convert wind energy into electrical energy. This research applies the maximum power point tracking (MPPT) algorithm combined with the fuzzy sliding mode control (FSMC) to produce maximum power in the wind turbine. Addition of fuzzy logic algorithm to sliding mode control to reduce the chattering phenomenon caused by the high switching frequency of the MOSFET in the boost converter. The permanent magnet synchronous generator (PMSG) type of generator with a capacity of 600 watts is used to convert the mechanical energy of the turbine into electrical energy. Tracing the maximum power value of the generator with the MPPT-FSMC algorithm in this study based on the value of the generator output voltage, generator output current, and converter output voltage obtained through simulations on MATLAB / SIMULINK. Comparison of wind turbine performance using MPPT-FSMC and without MPPT is shown as validation of improved wind turbine performance when using intelligent control algorithm.
\end{abstract}

\section{INTRODUCTION}

There are many sources of electrical energy, one of them is wind turbine. Wind turbines are a renewable energy source that is widely developed to meet the need for electrical energy, especially in locations that have considerable wind energy potential [1]. The wind turbine system consists of two main parts, namely the blade and generator. The blade rotates based on the wind speed and the pitch angle, while the generator rotates to convert the mechanical energy from the blade into electrical energy $[2,3]$. The electrical energy generated by the generator varies depending on the rotation speed $(\omega)$, the structure of the wind turbine and the type of generator [4]. The type of generator that is often used is the Permanent Magnet Synchronous Generator (PMSG) [5].

Permanent Magnet Synchronous Generator (PMSG) is a generator that can excite electrical power without external magnetization [5], and can be used in large scale wind turbine installations (high power) and small scale (low power) [6]. The electrical power generated by PMSG is three-phase electrical power, then rectified using a three-phase rectifier component, resulting in DC electrical power [7-9]. DC electric power can be controlled to produce maximum power using a boost converter Generator Side Controller (GSC) $[2,10,11]$ or it can be called a Machine Side Controller (MSC) [12]. Generator Side Control (GSC) is the part that is used to control the voltage from the rectifier, so as to produce a stable DC voltage in accordance with the load capacity. The important parts contained in the GSC are the control algorithm and the converter [13]. The converter is a component in the GSC which functions to convert the value of input power to output power with different values $[14,15]$. The converter based on its function is divided into 5 , namely boost converter, buck converter, buck - boost converter, cuk converter, and sepic converter.
Maximum Power Point Tracking (MPPT) is a control algorithm used to extract the maximum power at each rotational speed $(\mathrm{rad} / \mathrm{s})$ of the generator $[2,11,16,17]$. The maximum power extraction from the wind turbine generator can be carried out effectively in zone II. There are 4 zones for the wind turbine output power control strategy, namely zone I has a very small wind speed to generate power, Zone II generates power in the wind speed range between cut-in and average, zone III shows the average power of the wind turbines, and zone IV show the power of wind turbine has value $0\left(\mathrm{~V}_{\text {cut- }}\right.$ off) [2]. The conventional MPPT algorithm is divided into 2, namely Indirect Power Control (IPC) and Direct Power Control (DPC) [2]. IPC is an MPPT algorithm that uses the value of wind speed (Vwind) as the main parameter to adjust the switching frequency of the converter, such as Tip Speed Ratio (TSR), Optimum Torque (OT), and Power Signal Feedback (PSF). While the DPC algorithm requires a wind turbine rotation speed value as an input parameter for controllers such as Perturb \& Observe (P\&O), such as Hill Climb Search (HCS), and Optimum Relatio Based (ORB) [2]. The weakness of the two types of MPPT algorithm is that it uses a lot of sensors that involve mechanical work such as wind speed sensors and wind turbine rotation speed sensors, so that it can reduce the efficiency of the measurement results.

This research combines intelligent control algorithms, namely a fuzzy logic system with a sliding mode control at maximum power point tracking (MPPT). The application of the MPPT algorithm - fuzzy sliding mode control (FSMC) on the wind energy conversion system (WECS) does not require input data in the form of wind speed, rotation speed (rpm), and torque values, but only uses voltage and current data generated by the generator and voltage output of the boost converter as input variable to MPPT block [16]. This can save the use of sensors during the data retrieval process. This method can track the maximum power in a shorter time, because the fuzzy 
- sliding mode control algorithm has the characteristics of being able to overcome the fluctuation of the generator output power through the control signal settings given to the MOSFET to regulate the duty cycle.

\section{SYSTEM CONFIGURATION OF WIND TURBINE}

The sketch of the wind turbine system in this study is shown in Figure $1[14,18,19]$. The wind turbine used is the Variable Speed Wind Turbine (VSWT) type and has a total of 3 blades. VSWT can be used in fluctuating wind conditions, because it can adjust the rotation speed of the generator and wind speed. The Permanent Magnet Synchronous Generator (PMSG) is connected to the blade through the axle, allowing efficient energy transfer from blade rotation. The ratio between the electric power (AC) produced by PMSG and the mechanical power of the turbine is called the power coefficient $(\mathrm{Cp})$. The
Betz Limit theory explains that each wind turbine has a maximum $\mathrm{Cp}$ value of 0.59 . This shows that the maximum value of energy from the blade that can be converted into electric power is $59 \%$. AC power (3 phases) from the generator is converted into DC electricity through the diode rectifier component so that it can be controlled using a boost converter to achieve the Maximum Power Point (MPP). The load value on the boost converter can affect the rotation speed of the generator, because the greater the load value, the lower the generator rotation speed (rpm), so that the DC electric power that goes to the boost converter is also lower. The electrical energy produced by the VSWT type wind turbine is greater than the Fix Speed Wind Turbine (FSWT) type wind turbine, but the level of stability is low [20]. This can be overcome by manipulating the duty cycle value of the boost converter through the Maximum Power Point Tracking (MPPT) control algorithm [20].

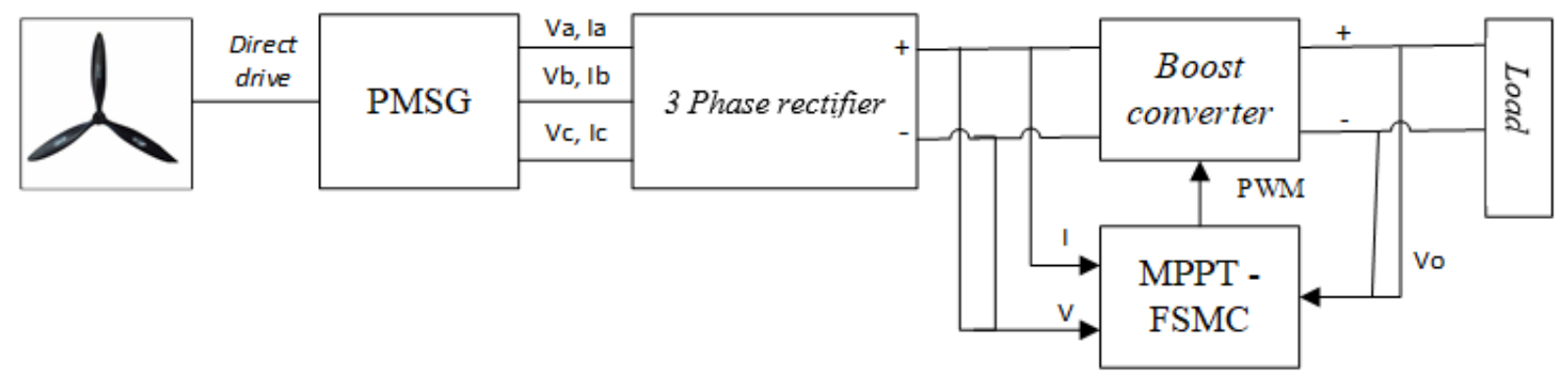

Figure 1. Wind turbine system configuration integrated with the MPPT - FSMC system

\section{MATHEMATICAL MODEL OF WECS}

The mathematical model of the wind energy conversion system (WECS) is obtained based on the characteristics of each component. The focus of mathematical modeling in this study is to obtain an illustration of the dynamic characteristics of the wind turbine system through Simulink / Matlab software. The important parts of the wind turbine system are shown in Figure 1, namely, the aerodynamic blade model, the turbine mechanical model, the PMSG model, the MPPT algorithm model, the boost converter model and the load $[1,4]$.

\subsection{Modelling of aerodynamic system}

The wind turbine aerodynamic system is obtained based on the relationship between wind energy passing through the blade with the energy absorbed by the blade to rotate the generator. Wind turbine mechanical energy generated from wind energy is written in the following equation [21-23].

$$
\begin{aligned}
& P_{m}=\frac{1}{2} \cdot \rho_{\text {air }} \cdot C_{p}(\lambda, \beta) \cdot A \cdot V_{\text {wind }}^{3} \\
& P_{w}=\frac{1}{2} \cdot \rho_{\text {air }} \cdot C_{p}(\lambda, \beta) \cdot \pi \cdot R^{2} \cdot V_{\text {wind }}{ }^{3}
\end{aligned}
$$

where, $\mathrm{Pw}$ is the mechanical power of the wind turbine (Watt), $\rho_{\text {air }}$ is the density of air $\left(\mathrm{kg} / \mathrm{cm}^{3}\right), V_{\text {wind }}$ is the wind speed ( $\mathrm{m}$ / $\mathrm{s}$ ), $\mathrm{R}$ is the radius of the blade ( $\mathrm{m}), \mathrm{Cp}$ is the power coefficient of aerodynamics, $\beta$ is the pitch angle (degrees), and $\lambda$ is the tip speed ratio (TSR) [1, 18, 24].

The power coefficients in the $\lambda$ and $\beta$ domains are obtained based on the following equation [25-27].

$$
\begin{gathered}
C_{p}(\lambda, \beta)=C_{1} \cdot\left(\frac{C_{2}}{\lambda_{i}}-C_{3} \cdot \beta-C_{4}\right) \cdot \exp \left(\frac{-C_{5}}{\lambda_{i}}\right)+C_{6} \cdot \lambda \\
\frac{1}{\lambda_{i}}=\frac{1}{\lambda+0,08 \beta}-\frac{0,035}{\beta^{3}+1}
\end{gathered}
$$

where [18, 28, 29],

$$
\lambda=\frac{r \Omega}{V_{\text {wind }}}
$$

$\mathrm{C}_{1}=0,5176 ; \mathrm{C}_{2}=116 ; \mathrm{C}_{3}=0,4 ; \mathrm{C}_{4}=5 ; \mathrm{C}_{5}=21 ; \mathrm{C}_{6}=0,0068$ $[1,14]$. Eqns. (1) to (5) can be used to determine the relationship between the mechanical power of the wind turbine and the wind turbine rotation speed shown by the graph plot in Figure 2 [30, 31].

Figure 2 is a graph of the characteristics of the wind turbine mechanical power (Watt) to the generator rotation speed (rad / s) at each wind speed value. The graph of the wind turbine power is generated when the value is $\beta$ (pitch degrees) from wind turbine value at 0 , so that there is no braking process or all wind energy is converted into wind turbine mechanical power. 


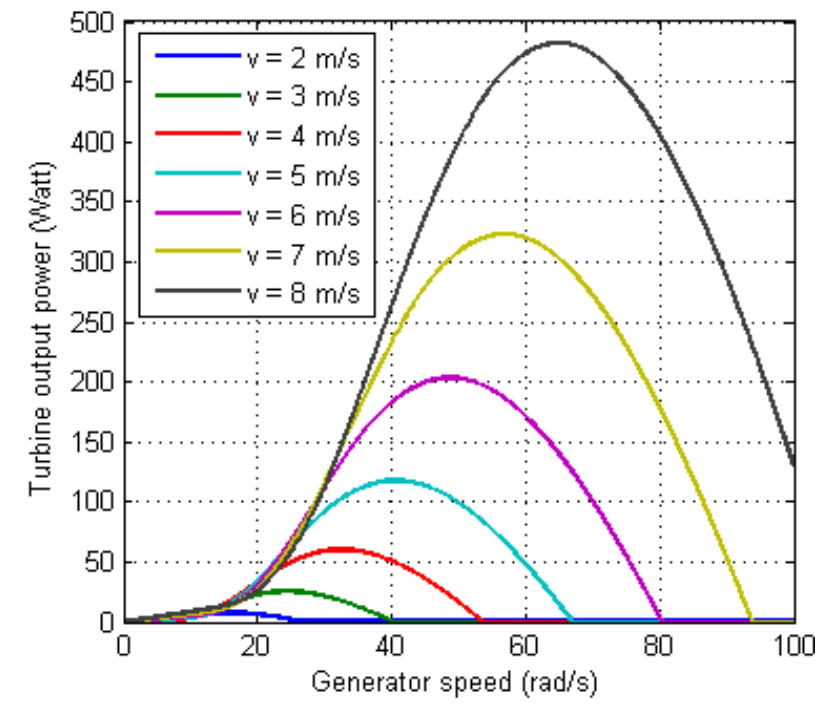

Figure 2. Characteristics of wind turbine mechanical power to generator rotation speed

\subsection{Modelling of mechanical system}

The mechanical model of the wind turbine can be viewed from the rotation of the wind turbine and generator rotors connected through the axle / shaft, so that a linear value is obtained between the two. The mathematical model of the 2 dynamic systems can be written as follows [1].

$$
\begin{gathered}
\dot{\omega}=\left(T_{t}-T_{g}-F_{\omega}\right) / J \\
T_{g}=\left\{\begin{array}{c}
0, V<V_{c i} \\
k_{o p t} \omega^{2}, V_{c i} \leq V \leq V_{r a t} \\
T_{r a t}, V_{r a t}<V<V_{c t}
\end{array}\right\}
\end{gathered}
$$

where, $\omega_{\mathrm{m}}$ is the angular velocity of the wind turbine shaft $(\mathrm{rad} / \mathrm{s}), \mathrm{Tt}$ is the blade torque $(\mathrm{Nm}), \mathrm{Tg}$ is the generator torque $(\mathrm{Nm}), \mathrm{F}$ is the viscous friction coefficient, $\mathrm{V}_{\mathrm{ci}}$ is the wind turbine cut-in speed $(\mathrm{m} / \mathrm{s}), \mathrm{V}_{\text {rated }}$ is wind turbine average speed $(\mathrm{m} / \mathrm{s})$, and $\mathrm{V}_{\mathrm{ct}}$ is the wind turbine cut-off speed $(\mathrm{m} / \mathrm{s})$ [1].

The wind turbine system with a PMSG type generator can be connected without using a gear box, but only using axles/shaft. The rotation of the generator is linear with the rotation of the axle/shaft which has a torque value in accordance with the ratio of the mechanical power to the generator load $[2,5]$.

$$
T_{w}=\frac{P_{w}}{\Omega_{m}}=\frac{1}{2} \cdot \rho \cdot \pi \cdot R^{2} \frac{V^{3} w}{\Omega_{m}} \cdot C p
$$

where,

Velocity

$$
\begin{gathered}
\int_{t_{i}}^{t_{j}} P_{w} \cdot d t-\int_{t_{i}}^{t_{j}} P_{i n} \cdot d t=K \cdot\left(n_{j}{ }^{2}-n_{i}{ }^{2}\right) \\
K=\frac{J \cdot\left(\frac{2 \pi}{60}\right)^{2}}{2}
\end{gathered}
$$

where, $\mathrm{J}$ is inertia moment, $\mathrm{Pi}_{\mathrm{n}}$ and $\mathrm{P}_{\mathrm{out}}$ is input power and output power of generator. Eq. (9) shows that wind turbine power and generator input power always change with time in a certain period. These changes depend on the generator workload, if the generator workload has increased, the power generated will also be even greater [22].

\subsection{Modelling of PMSG}

Permanent magnet synchronous generator (PMSG) has an important part to excite electrical power, namely the rotor. Mechanically, the rotor at PMSG has 2 important parts, namely the direct (d) axis and the quadrature (q) axis [32]. The 3 -phase AC voltage is generated by PMSG, each of which has a difference of $120^{\circ}$ angles as shown in Figure 3 below [22, 32].

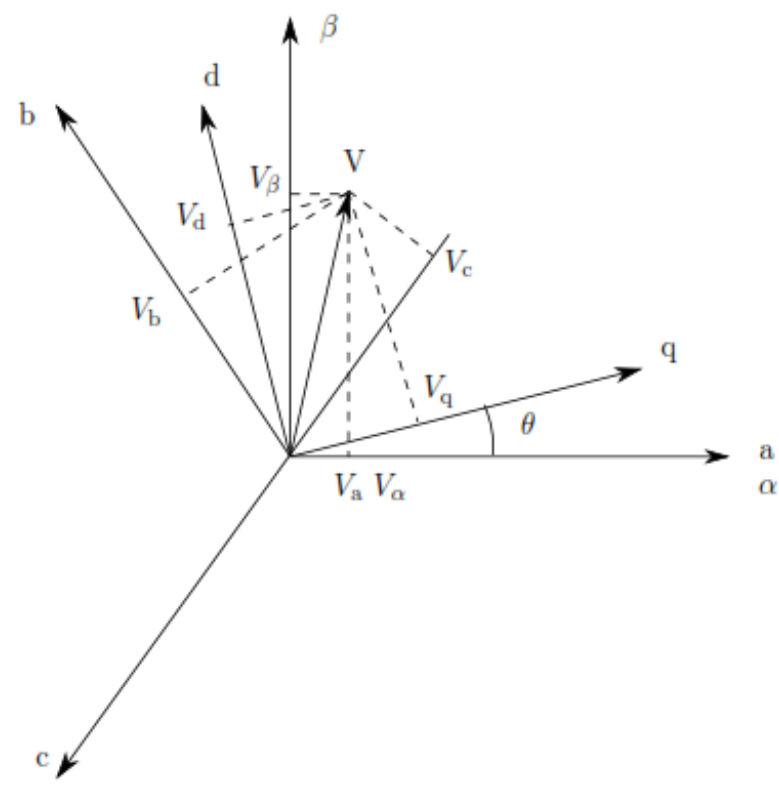

(a) Voltage vector

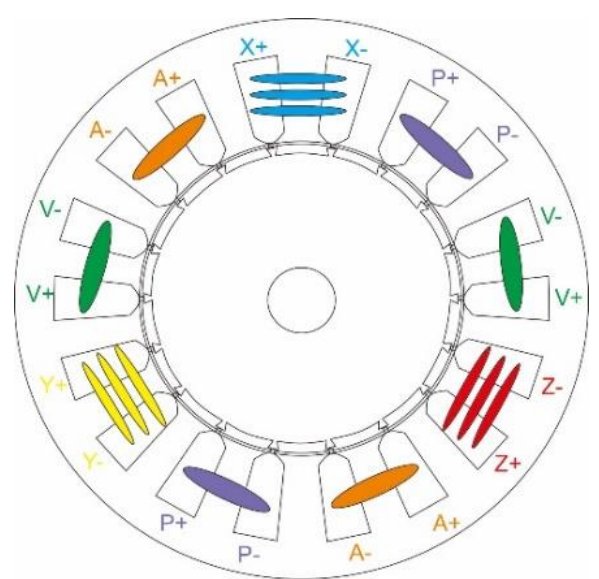

(b) Pole generator pairs

Figure 3. Vector on 3 phase generator

The difference in the angle of the 3-phase voltage on the stator which is denoted by the vectors $\mathrm{a}, \mathrm{b}, \mathrm{c}$ can be converted into alpha $(\alpha)$ and beta $(\beta)$ vectors using Clark Transformation [32].

$$
V_{\alpha}=\frac{2}{3}\left(V_{a}-\frac{1}{2} V_{b}-\frac{1}{2} V_{c}\right)
$$




$$
V_{\beta}=\frac{1}{\sqrt{3}}\left(V_{b}-V_{c}\right)
$$

where, $\mathrm{V} \alpha$ is the stator voltage in the alpha vector $(\alpha)$ and $\mathrm{V} \beta$ is the stator voltage in the beta vector $(\beta)$. The voltages $V \alpha$ and $\mathrm{V} \beta$ excited by the generator are affected by the magnitude of the electric angle $(\theta \mathrm{e})$ at the stator [32].

$$
\theta_{e}=N_{P} \cdot \theta_{m}
$$

where, $\mathrm{Np}$ is the number of poles on the generator, and $\theta \mathrm{m}$ is the mechanical angle of the rotor. The shift in the value of the electric angle $(\theta \mathrm{e})$ can cause a change in the value of the voltage vector on the generator, so that a mathematical model of the generator is obtained based on the stress vector on the $\mathrm{q}$ (Vq) and $\mathrm{d}(\mathrm{Vd})$ axes using Park Transformation [32].

$$
\begin{gathered}
V_{q}=V_{\alpha} \cos \theta_{e}+V_{\beta} \sin \theta_{e} \\
V_{d}=-V_{\alpha} \sin \theta_{e}+V_{\beta} \cos \theta_{e}
\end{gathered}
$$

Eqns. (13) and (14) show that the value of the electric angle $(\theta \mathrm{e})$ affects the voltage generated by the generator. The voltage vectors $\mathrm{Vq}$ and $\mathrm{Vd}$ as shown in Figure 3a have a phase difference of 90 degrees, so that in equation 14 there is a minus sign (-) which indicates the difference in direction between the $\mathrm{d}$ axis and the $\mathrm{q}$ axis [32]. The voltage vectors $\mathrm{Vq}$ and $\mathrm{Vd}$ if illustrated in the RL circuit are influenced by the value $\omega$ (angular velocity) of the stator shown in Figure 4 below [15, $16,32]$.
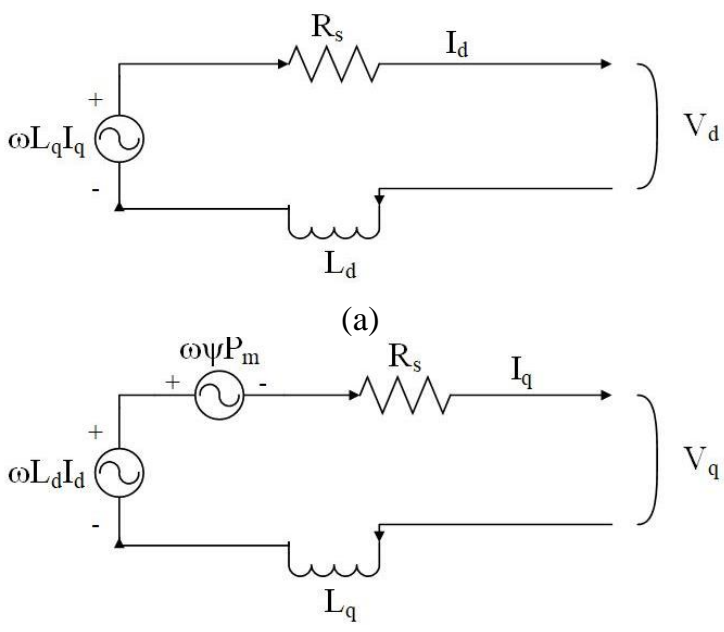

(b)

Figure 4. The circuit RL of the voltage vector (a) d axis; (b) q axis

The circuit in Figure 4 can be written in the form of a mathematical model as in Eqns. (16) and (17) below [15, 32, 33].

$$
\begin{gathered}
V_{q}=-R_{s} I_{q}-L_{q} \frac{d I_{q}}{d t}+\omega_{e} \psi_{p m}-\omega_{e} L_{d} I_{d} \\
V_{d}=-R_{s} I_{d}-L_{d} \frac{d I_{d}}{d t}+\omega_{e} L_{q} I_{q}
\end{gathered}
$$

where, Rs is resistance of stator $(\Omega), \mathrm{Lq}$ and $\mathrm{Ld}$ is stator inductance on $\mathrm{q}$ axis and $\mathrm{d}$ axis $(\mathrm{H}), \mathrm{Id}$ and $\mathrm{Iq}$ is current on $\mathrm{d}$ axis and $\mathrm{q}$ axis $(\mathrm{A}), \omega_{\mathrm{e}}$ is electric angular velocity of stator $(\mathrm{rad} / \mathrm{s})$ [34], $\psi_{\mathrm{pm}}$ is permanent magnetic flux [15]. The combination of the $\mathrm{d}$ and $\mathrm{q}$ axis components on the stator can produce the electric power $(\mathrm{Pe})$ value of the generator as shown in the following equation [32],

$$
P_{e}=\frac{3}{2}\left(V_{q} I_{q}+V_{d} I_{d}\right)
$$

while electromagnetic torque [35],

$$
T_{e m}=\frac{3}{2}\left(\frac{p}{2}\right)\left(\psi_{p m} \cdot I_{q}+\left(L_{d}-L_{q}\right) I_{d} I_{q}\right)
$$

where, $p$ is the number of pole pairs. Magnets are an important part of the generator which is installed with the same size on the surface of the rotor. This results in the value of $\mathrm{L}_{\mathrm{d}}$ and $\mathrm{L}_{\mathrm{q}}$ being assumed to have the same value, so that the equation for electromagnetic torque can be written as follows $[15,16]$.

$$
T_{e}=p \cdot \psi_{p m} . I_{q}
$$

The electromagnetic torque ( $\mathrm{Te}$ ) of the generator is directly proportional to the current generated by the stator, so that the electromagnetic torque of the generator can be controlled by varying the stator current (Is) $[16,36]$. The $\mathrm{p}$ and $\Psi_{\mathrm{pm}}$ values in Eq. (19) are variables that have a fixed value, while the current in the stator will change according to the load on the generator, so that $\mathrm{Te}$ (electromagnetic torque) is proportional to Is (stator current) $[16,30]$.

Permanent magnet synchronous generator (PMSG) is connected to the wind turbine using the direct drive (gearless) method, so as to minimize the power loss. The mathematic equation for PMSG direct drive and wind turbine shaft can be written as follows $[11,35]$.

$$
j \frac{d \omega_{m}}{d t}+D \cdot \omega_{m}=T_{m}-T_{e}
$$

where, $\mathrm{j}$ is inertia moment of shaft $\left(\mathrm{kg} \cdot \mathrm{m}^{2}\right), \mathrm{D}$ is damping value of shaft $\left(\mathrm{kg} \cdot \mathrm{m}^{2} / \mathrm{s}\right), \mathrm{Tm}$ is mechanical torque of shaft (N.m), and Te is electromagnetic torque of generator (N.m). The value of E for PMSG which is connected directly through the shaft with a wind turbine (direct drive) and has a constant magnetic flux value can be determined by the following equation $[3,16]$.

$$
E=K_{e} . \psi_{p m} . \omega
$$

where, E is the back electromotive force (Volt) caused by the induction of voltage on the PMSG coil [14] and $\mathrm{Ke}$ is the electromotive power coefficient [6]. The steady state condition at generator rotation produces the terminal voltage value at the stator (Vs) which can be determined using the following equation $[14,30]$.

$$
V_{s}=E-I_{s}\left(R_{s}+j \omega_{e} \cdot L_{s}\right)
$$

where, Vs is stator voltage, (Volt) Ls is inductance of stator (H). 


\subsection{Modelling of three phase rectifier diode}

The three-phase rectifier diode is a component that functions to convert the 3-phase AC voltage from the generator output to the DC voltage shown in the following scheme [37].

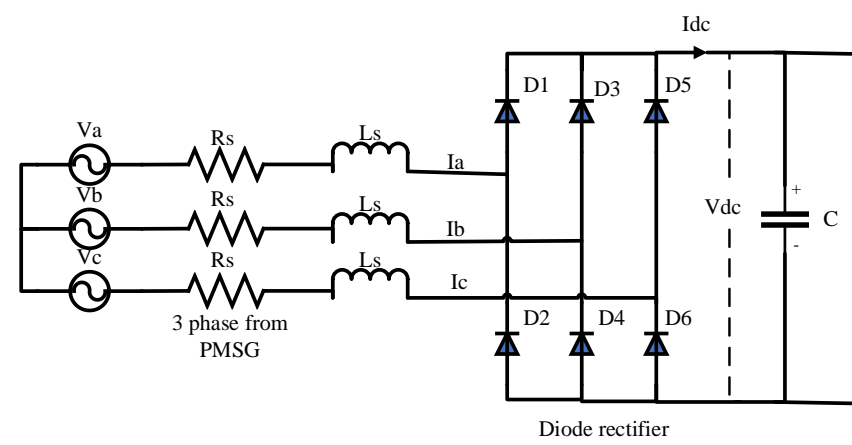

Figure 5. Three phase rectifier circuit connected to a 3 phase generator

Figure 5 above is a full wave 3 phase rectifier circuit with 6 diodes which have different switching times. The output of the rectifier circuit is a DC current $[3,14,16]$.

$$
I_{d c}=\frac{\pi}{2 \sqrt{3}} \cdot \sqrt{I_{q}{ }^{2}+I_{d}{ }^{2}}
$$

and DC voltage [38].

$$
\begin{gathered}
V_{d c}=\frac{3 \sqrt{6}}{\pi} V_{s} \\
V_{d c}=\frac{3 \sqrt{6}}{\pi} \cdot E-I_{s}\left(R_{s}+j \cdot \omega_{e} \cdot L_{s}\right)
\end{gathered}
$$

where, Idc and Vdc are DC current (A) and DC voltage (Volt) respectively.

\subsection{Modelling of boost converter}

The boost converter in the wind turbine system functions to convert the input voltage (Vin) to an output voltage (Vout) with a larger value as shown in Figure 6 below [39].

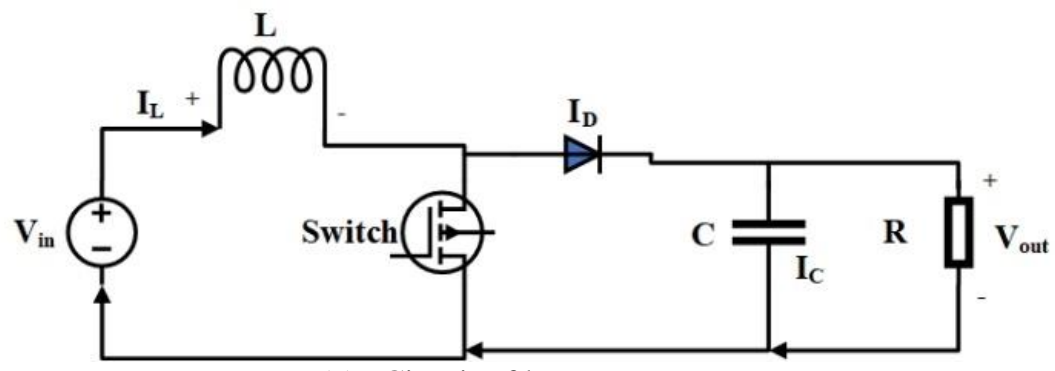

(a) Circuit of boost converter

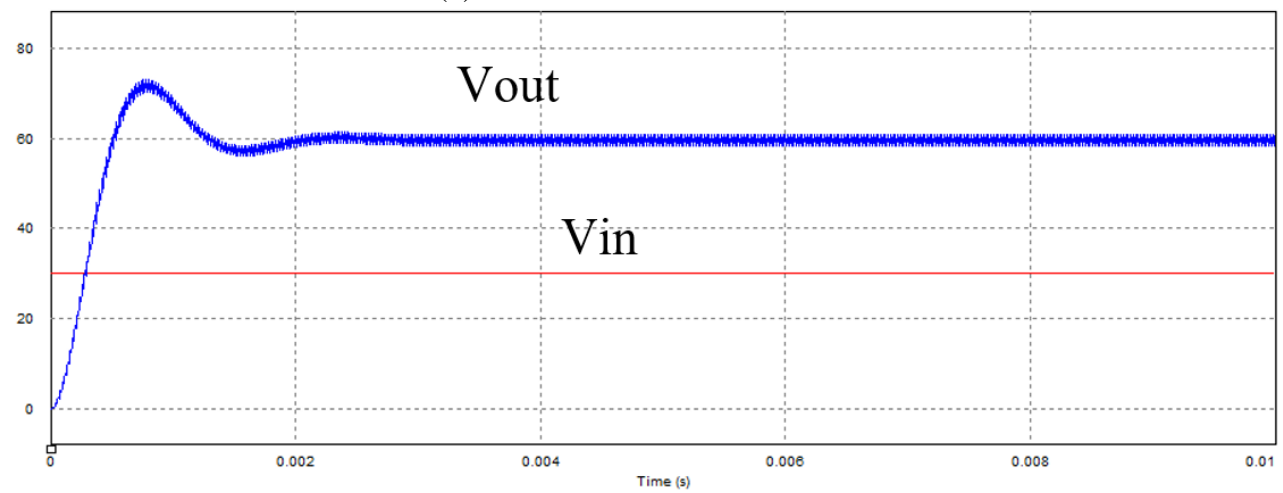

(b) Graph of input voltage and output voltage

Figure 6. Design of boost converter

Table 1. Boost converter specifications

\begin{tabular}{cc}
\hline Component & Value \\
\hline Input voltage $\left(\mathrm{V}_{\text {in }}\right)$ & 30 Volt \\
Output voltage $\left(\mathrm{V}_{\text {out }}\right)$ & $60 \mathrm{Volt}$ \\
Inductance $(\mathrm{L})$ & $500 \mu \mathrm{H}$ \\
Capacitance $(\mathrm{C})$ & $50 \mu \mathrm{F}$ \\
Switching frequency of & $25 \mathrm{kHz}$ \\
MOSFET & \\
\hline
\end{tabular}

The output voltage ripple value $\left(\mathrm{V}_{\text {out }}\right)$ is generated based on the switching frequency on the MOSFET, the greater the switching frequency value on the mosfet, the smaller the ripple $\mathrm{V}_{\text {out }}$, and vice versa, the smaller the frequency value on the
MOSFET, the greater the ripple $\mathrm{V}_{\text {out. }}$ The output voltage response in Figure $6 \mathrm{~b}$ is generated based on the component specifications shown in Table 1.

The dynamic model of the boost converter is obtained based on changes in the value of the output voltage $\left(\mathrm{V}_{\text {out }}\right)$, input voltage $\left(\mathrm{V}_{\text {in }}\right)$ and current (I) input converter which can be written in the form of differential equations [40]. The mathematical model for the inductor current can be written as follows.

$$
\frac{d x_{1}}{d t}=-(1-u) \frac{1}{L} x_{2}+\frac{V_{i n}}{L}
$$


As for the capacitor voltage,

$$
\frac{d x_{2}}{d t}=(1-u) \frac{1}{C} x_{1}-\frac{1}{R C} x_{2}
$$

where, $\mathrm{x} 1$ is the inductor current, $\mathrm{x} 2$ is the boost converter output voltage, $\mathrm{V}_{\text {in }}$ is the converter input voltage (Volt), $\mathrm{C}$ is the capacitance value $(\mu \mathrm{F}), \mathrm{L}$ is the inductance value $(\mathrm{mH}), \mathrm{R}$ is the load resistance value (Ohm), and $\mathrm{u}$ is the value duty cycle [40]. Eqns. (28) and (29) can be represented in the form of state space as follows.

$$
\left[\begin{array}{c}
\dot{x}_{1} \\
\dot{x}_{2}
\end{array}\right]=\left[\begin{array}{cc}
0 & \frac{-(1-u)}{L} \\
\frac{(1-u)}{C} & -\frac{1}{R C}
\end{array}\right]\left[\begin{array}{l}
x_{1} \\
x_{2}
\end{array}\right]+\left[\begin{array}{c}
\frac{1}{L} \\
0
\end{array}\right] V_{i n}
$$

The boost converter in this study functions to control the value of the generator output power based on the size of the duty cycle. Changes in the value of the duty cycle can affect the rotation speed of the generator. The greater the duty cycle value, the lower the generator rotation speed will be.

Wind speed fluctuation causes the generator rotation is not constant, which causes the generator output voltage to become unstable. The addition of a capacitor to the boost converter input as shown in Figure 6a functions as a filter, so that the boost converter input voltage becomes stable as shown in Figure $6 b$.

\section{DESIGN OF MAXIMUM POWER POINT TRACKING}

Maximum power point tracking (MPPT) is a control algorithm used to increase wind turbine output power, so that the maximum output power value is obtained at each change in rotor speed. The MPPT algorithm used in wind turbines is divided into 2, namely conventional MPPT algorithms such as HCS, TSR, PSF [41, 42] and the MPPT algorithm with intelligent controls such as fuzzy sliding mode control (FSCM).

\subsection{Fuzzy Sliding Mode Control (FSCM)}

Sliding Mode Control (SCM) is one of the nonlinear control algorithms that has the working principle of maintaining the system trajectory to work on the surface line area, resulting in a stable response at the set point value. An important part of the SCM algorithm is designing the switching surface or sliding surface $S(x)$. The maximum power can be achieved if the ratio of power change to voltage change is zero as shown in the following equation $[2,43]$.

$$
\frac{d P_{g e n}}{d V_{g e n}}=0
$$

The sliding surface in this study is based on the incremental conductance (INC) method, so that Eq. (31) can be written as follows $[2,43]$.

$$
\begin{gathered}
S(t)=\frac{d P_{g e n}}{d V_{g e n}}=\frac{d(V I)_{g e n}}{d V_{g e n}}=I_{g e n}+V_{g e n} \frac{d I_{g e n}}{d V_{g e n}}=0 \\
U_{n}(t)=-k_{s} \cdot \operatorname{sign}(s) \\
U_{e q}(t)=1-\frac{V_{g e n}}{V_{\text {out }}} \\
U(t)=U_{n}(t)+U_{e q}(t)
\end{gathered}
$$

The sliding mode control produces the duty cycle value based on the sum of the variables Un and Ueq. The Ueq variable serves to bring the system to the surface line area, while the Un variable functions to maintain system stability when it reaches the sliding surface area [43].

System stability can be evaluated using Lyapunov's stability theory.

$$
\begin{aligned}
& V=\frac{1}{2} S^{2}(t) \\
& \dot{V}=S(t) \dot{S}(t)
\end{aligned}
$$

The value of $\dot{S}(t)$ is divided into 3 conditions based on the stability of the power generated by the generator when it reaches the maximum power point value (MPP).

$$
\dot{S}(t)=\left\{\begin{array}{c}
<0, S(t)>0 \longrightarrow \dot{S}(t)<0 \\
=0, S(t)=0 \\
>0, S(t)<0 \longrightarrow \dot{S}(t)>0
\end{array}\right\}
$$

The system will reach a point of origin $(0,0)$ or a point of stability if variable $\dot{V}$ less than $0(\dot{V}<0)$.

$$
S(t)=I_{g e n}+V_{g e n} \frac{d I_{g e n}}{d V_{g e n}}=0
$$

$$
\begin{gathered}
S(t)=\frac{\pi}{2 \sqrt{3}} \sqrt{I_{q}{ }^{2}+I_{d}{ }^{2}}+ \\
\left(\frac{3 \sqrt{6}}{\pi} E-I_{s}\left(R_{s}+j \omega_{e} \cdot L_{s}\right)\right) \frac{d I_{g e n}}{d V_{g e n}} \\
S(t)=\frac{\pi}{2 \sqrt{3}} \sqrt{\left(\frac{\phi_{q}}{L_{q}}\right)^{2}+\left(\frac{\phi_{d}-\phi m}{L_{d}}\right)^{2}} \\
+\left(\frac{3 \sqrt{6}}{\pi} E-I_{s}\left(R_{s}+j \omega_{e} \cdot L_{s}\right)\right) \cdot 0 \\
S(t)=\frac{\pi}{2 \sqrt{3}}\left(\frac{\phi_{q}}{L_{q}}+\frac{\phi_{d}-\phi_{m}}{L_{d}}\right)
\end{gathered}
$$




$$
S(t)=\frac{\pi}{2 \sqrt{3}} \frac{\phi_{q}}{L_{q}}+\frac{\pi}{2 \sqrt{3}} \frac{\phi_{d}}{L_{d}}-\frac{\pi}{2 \sqrt{3}} \frac{\phi_{m}}{L_{d}}
$$

To get the derivative of $S(t)$, then

$$
\begin{gathered}
\dot{S}(t)=\frac{d S(t)}{d V / g e n} \cdot \frac{d V / g e n}{d t} \\
\dot{S}(t)=-\left(-\frac{\pi}{2 \sqrt{3}} \frac{\phi_{q}}{L_{q}}-\frac{\pi}{2 \sqrt{3}} \frac{\phi_{d}}{L_{d}}+\frac{\pi}{2 \sqrt{3}} \frac{\phi_{m}}{L_{d}}\right) \frac{d}{d t}
\end{gathered}
$$

The summarize of MPPT equation is illustrated by the flowchart on Figure 7 below.

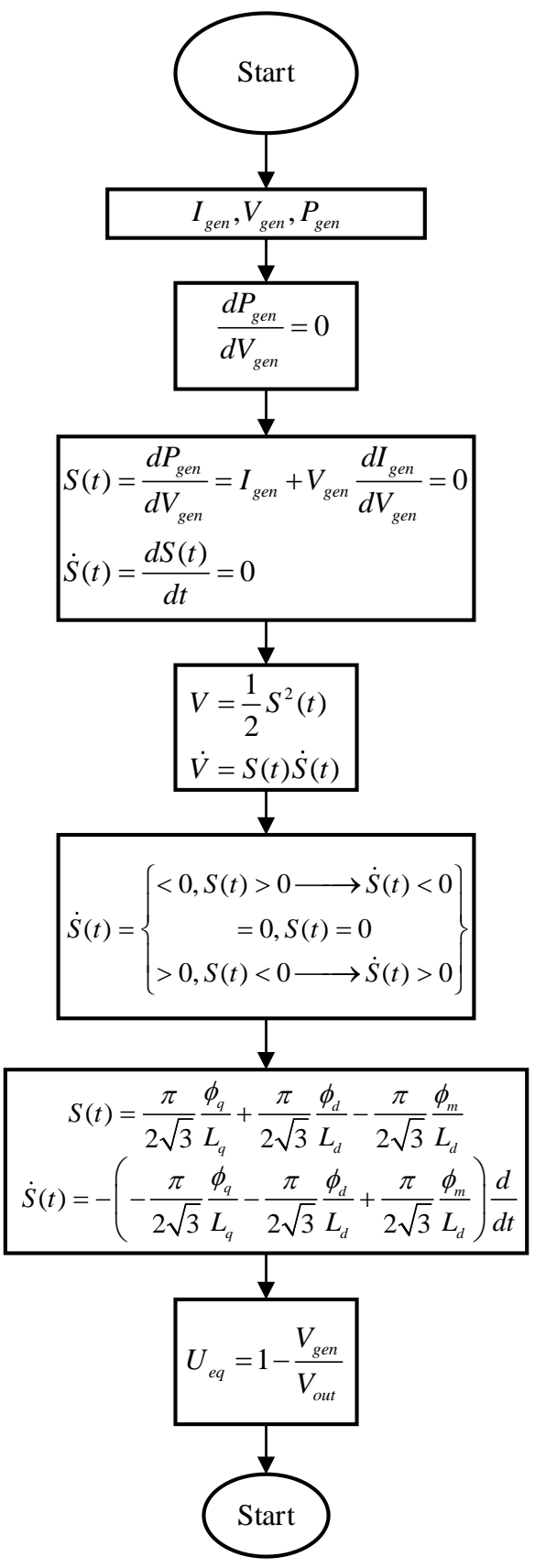

Figure 7. Flowchart of MPPT equation

The addition of fuzzy logic algorithms to sliding mode control functions to eliminate chattering or oscillation phenomena that can disrupt the stability of the wind turbine output power. The emergence of chattering is caused by a feedback response with a very high switching frequency (high speed switching feedback) from the SCM.

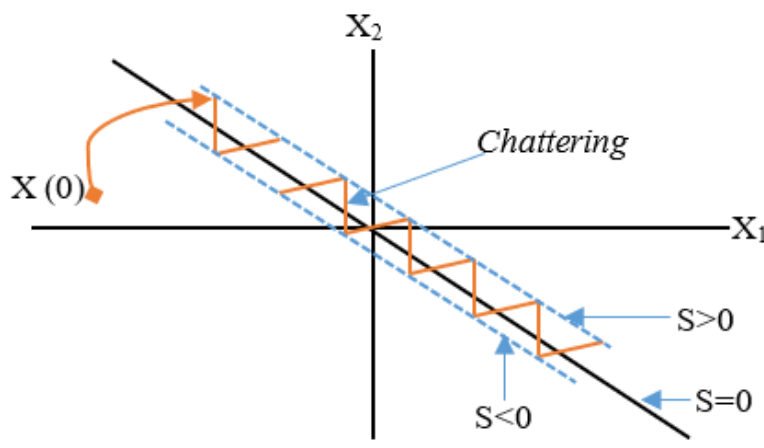

Figure 8. State process $\mathrm{X}(0)$ to sliding surface $(S=0)$

Figure 8 shows state $\mathrm{X}(0)$ moving towards the glide surface area. There are 3 conditions for the value of the output power generated by the wind turbine, namely when $S<0$ indicates the power value is to the right of the peak point, $S=0$ indicates the power value is at the peak point, and $S>0$ indicates the power value is to the left of the peak point. The value of power to voltage is obtained based on changes in the value of the duty cycle at each value of wind speed.

To be able to maintain the condition $\Delta \mathrm{P} / \Delta \mathrm{V}=0$ with a minimum chattering value, the fuzzy sliding mode control (FSMC) design in the wind turbine system is shown in the block diagram in Figure 9 below.

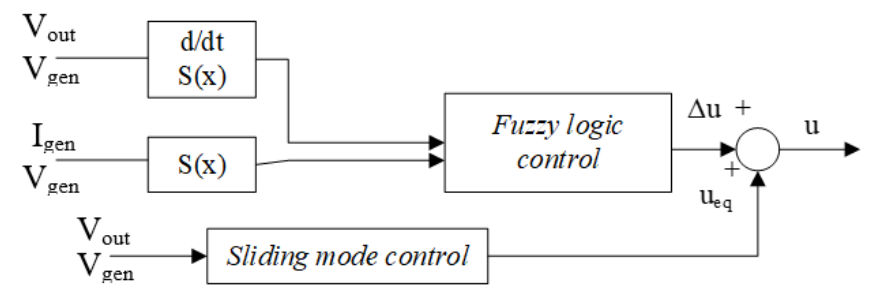

Figure 9. Fuzzy sliding mode control block diagram

Fuzzy logic control (FLC) block has 2 inputs, namely S (x) and derivative $\mathrm{S}(\mathrm{x})$. $\mathrm{I}_{\mathrm{gen}}, \mathrm{V}_{\mathrm{gen}}$, and $\mathrm{V}_{\text {out }}$ are the current in the inductor, the rectifier diode output voltage, and the boost converter output voltage. The value of duty cycle $(u)$ is obtained based on the sum of the output of fuzzy logic control $(\Delta \mathrm{u})$ and the equivalent value of sliding mode control $\left(\mathrm{u}_{\mathrm{eq}}\right)$.

$$
\begin{gathered}
u_{e q}=1-\frac{V_{g e n}}{V_{o u t}} \\
u=\Delta u+u_{e q}
\end{gathered}
$$

The combination of fuzzy algorithm and sliding mode control (SMC) causes the Un variable to be substituted by the $\Delta \mathrm{u}$ variable to eliminate chattering in the system response. Basically the Un and $\Delta u$ variables have the same goal, namely to reduce chattering, but have a different mechanism, namely the Un variable uses stability analysis with the Lyapunov method, while the $\Delta \mathrm{u}$ variable uses a fuzzy algorithm to reduce chattering. 
Figure 10a - 10c are triangular fuzzy membership function used to determine the duty cycle value of the boost converter based on the fuzzy rule base shown in Table 2 .

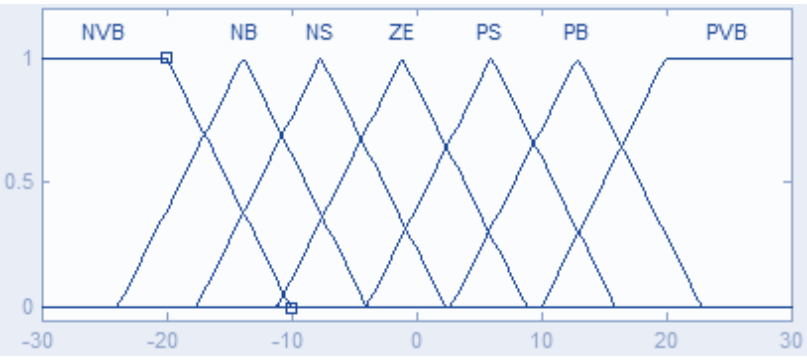

(a) Membership function of input $\mathrm{S}(\mathrm{x})$

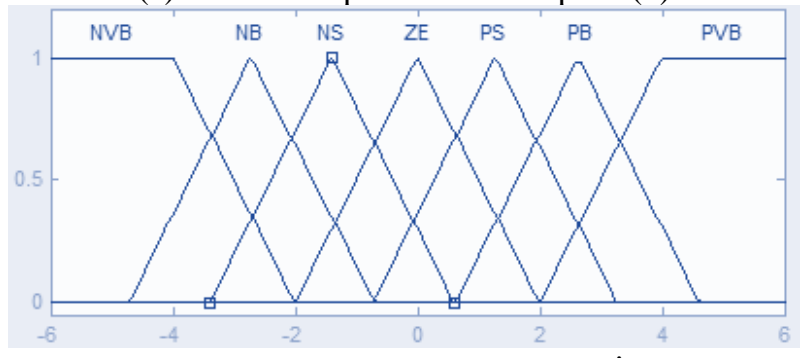

(b) Membership function of input $\dot{S}(\mathrm{x})$

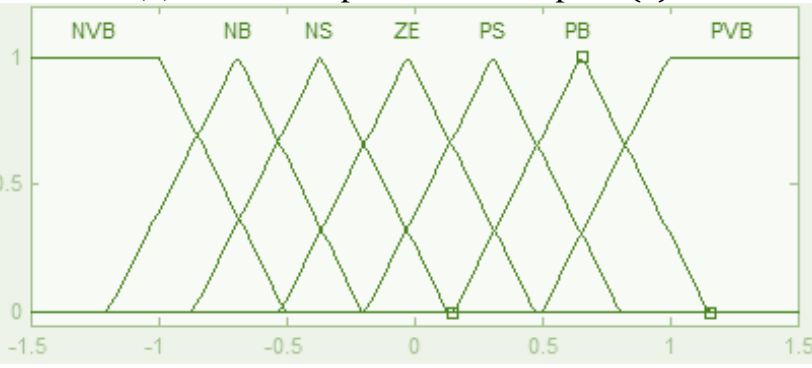

(c) Membership function of output $\Delta u$

Figure 10. Membership function of FLC

Table 2. Fuzzy rule base

\begin{tabular}{cccccccc}
\hline $\begin{array}{c}\text { S(x) } \\
\dot{\mathbf{S}}(\mathbf{x})\end{array}$ & \multirow{2}{*}{ NVB } & \multirow{2}{*}{ NB } & NS & ZE & PS & PB & PVB \\
\hline NVB & NVB & NVB & NVB & NVB & NB & NS & ZE \\
NB & NVB & NVB & NVB & NB & NS & ZE & PS \\
NS & NVB & NVB & NB & NS & ZE & PS & PB \\
ZE & NVB & NB & NS & ZE & PS & PB & PVB \\
PS & NB & NS & ZE & PS & PB & PVB & PVB \\
PB & NS & ZE & PS & PB & PVB & PVB & PVB \\
PVB & ZE & PS & PB & PVB & PVB & PVB & PVB \\
\hline
\end{tabular}

\section{SIMULATION RESULTS}

\subsection{Characterization of wind turbine output power}

Characterization of wind turbine output power is used to determine changes in the value of the power to the rectifier voltage $(\mathrm{P}-\mathrm{V})$ based on the value of the duty cycle on the boost converter. Wind speed is a variable that can affect the characteristics of the $\mathrm{P}-\mathrm{V}$ graph of the wind turbine generator as described in Figure 11.

Figure 11 is the result of characterizing the value of the output power against the wind turbine output voltage. The output voltage is in the form of a DC voltage or the generator output $\mathrm{AC}$ voltage that has been rectified using a 3-phase rectifier. There are 4 graphs that show the difference in wind speed, namely $3 \mathrm{~m} / \mathrm{s}, 4 \mathrm{~m} / \mathrm{s}, 5 \mathrm{~m} / \mathrm{s}$, and $6 \mathrm{~m} / \mathrm{s}$. The shift in the location of the peak point or power peak at each wind speed value against the voltage value is caused by the fluctuating DC current $\left(\mathrm{I}_{\mathrm{DC}}\right)$ value, so that the peak power at each wind speed cannot be drawn in a straight line.

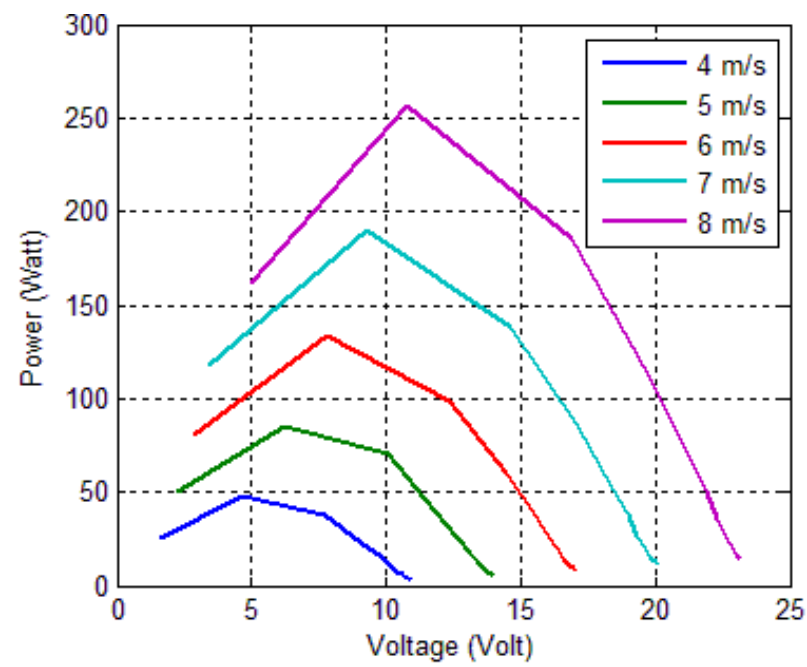

Figure 11. Wind turbine generator $\mathrm{P}$ - V curve

\subsection{System testing}

System testing is done by comparing the output power of the wind turbine without a controller and the output power of the wind turbine when using the MPPT control system - fuzzy sliding mode by providing a change in wind speed between 4 $-8 \mathrm{~m} / \mathrm{s}$ which is divided into two scenarios. There are 2 test scenarios in this paper, namely wind speed tracking testing and random wind speed testing.

\subsubsection{Wind speed tracking test}

The tracking test is carried out by providing a change in wind speed every 1 second as shown in Figure 12.

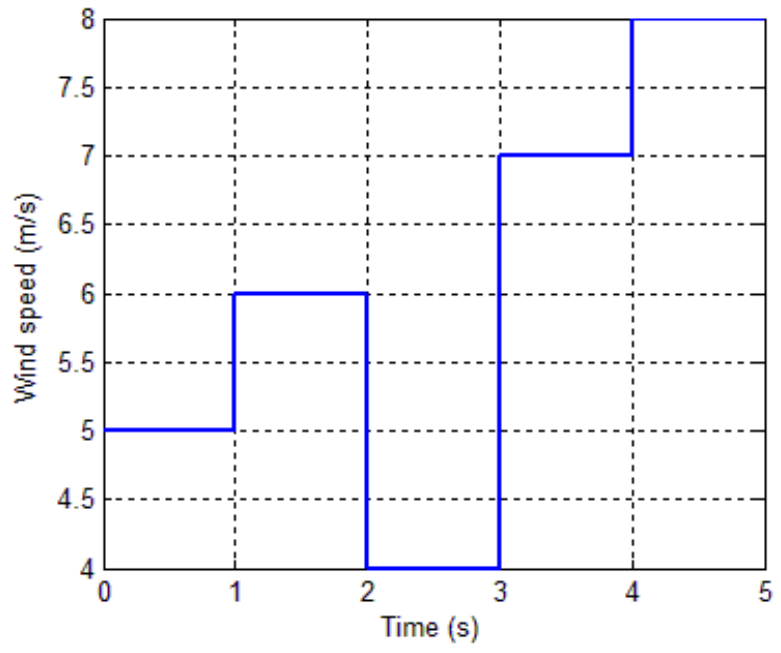

Figure 12. Wind speed profile tracking mode

Changes in the value of wind speed such as using step signals as shown in Figure 12 aims to test the performance of the MPPT - FSMC control system in controlling the output power of the wind turbine generator, so that the electric power generated by the generator can reach the maximum value. The rotor speed under wind speed tracking mode is shown on Figure 13 below. 


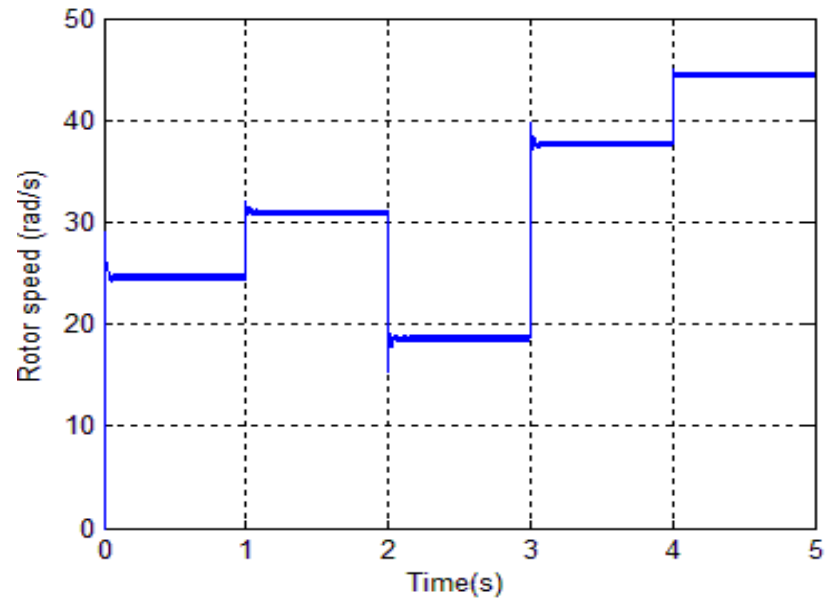

Figure 13. Rotor speed

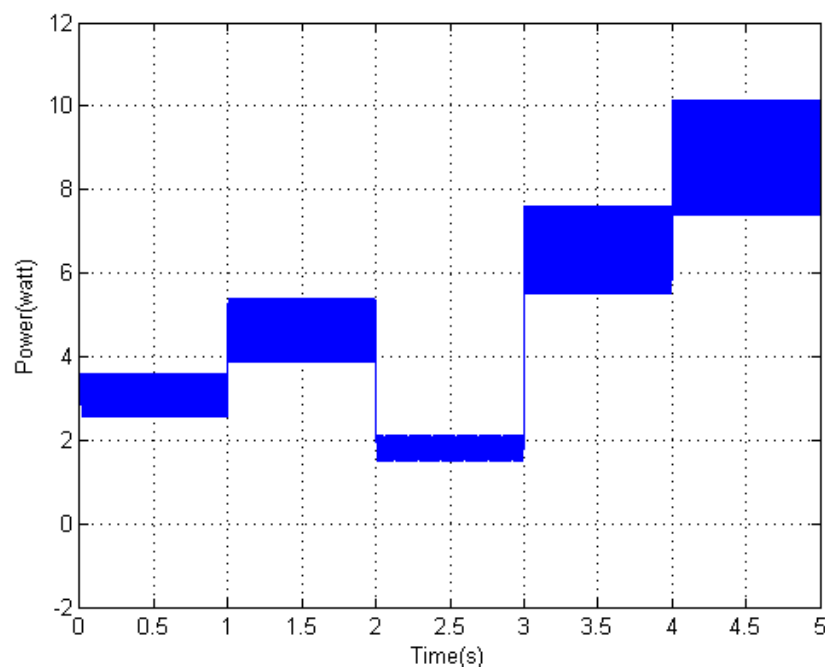

(a) No MPPT

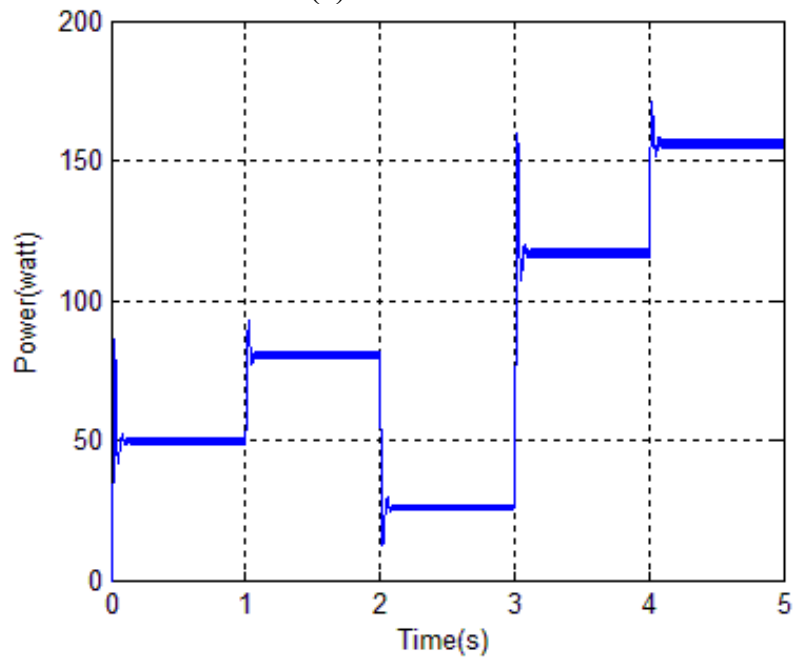

(b) Using MPPT-FSMC

Figure 14. Wind turbine generator output power comparison

Figure 14 above describes the change on the value of the generator output power during open loop (without MPPT) and close loop (using MPPT-FSMC). The changes on the value of the power generated by the generator at each sampling time are caused by changes on the value of wind speed at the same sampling time. This proves that the generator output power is greatly influenced by the changes of wind speed. The Power coefficient value under wind speed tracking mode is shown on Figure 15 below.

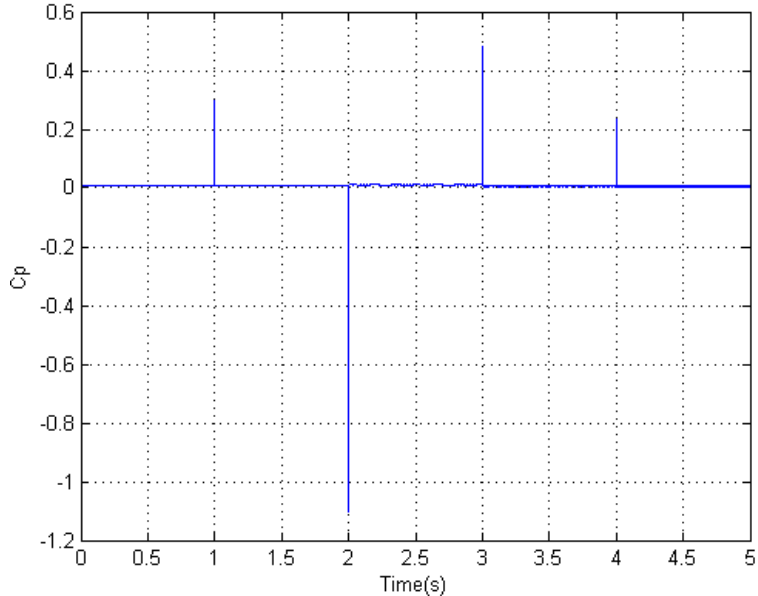

(a) No MPPT

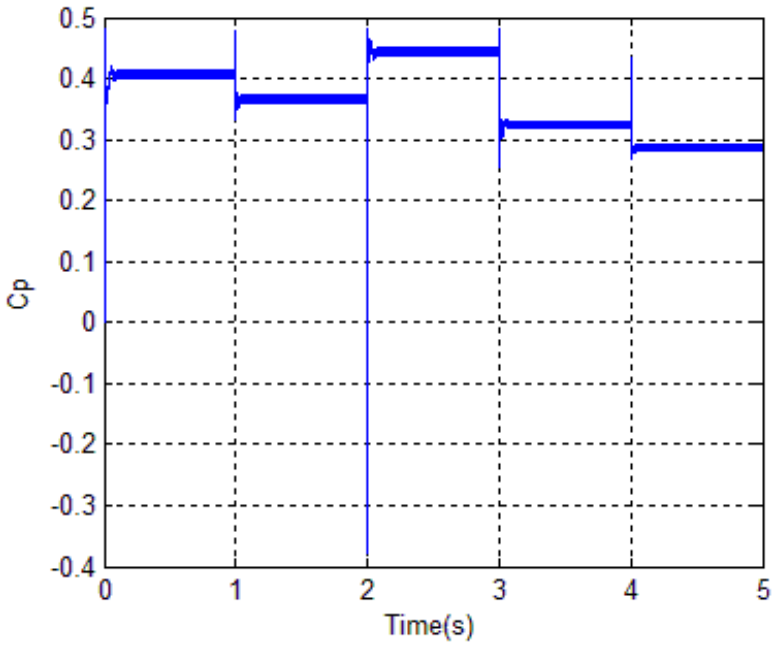

(b) Using MPPT-FSMC

Figure 15. Wind turbine $\mathrm{Cp}$ graph comparison

\subsubsection{Turbulent wind speed testing}

This test is carried out by providing a random wind speed with a range of $2 \mathrm{~m} / \mathrm{s}-8 \mathrm{~m} / \mathrm{s}$ as shown in Figure 16 .

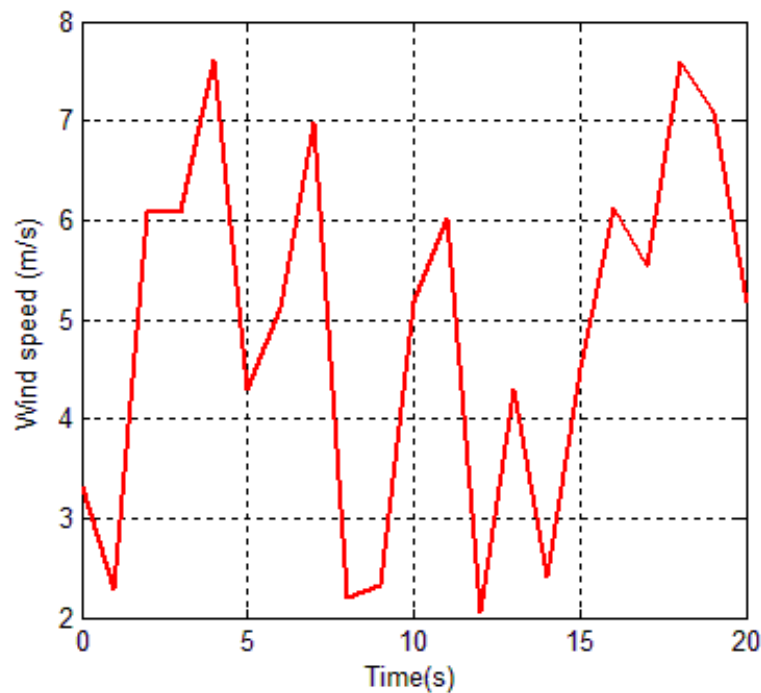

Figure 16. Turbulent mode of wind speed profile

Testing the performance of the MPPT-FSMC control system on the wind turbine system by providing the characteristics of turbulent wind speed, capable of producing an average output power of 63 Watts as shown in Figure 17. 


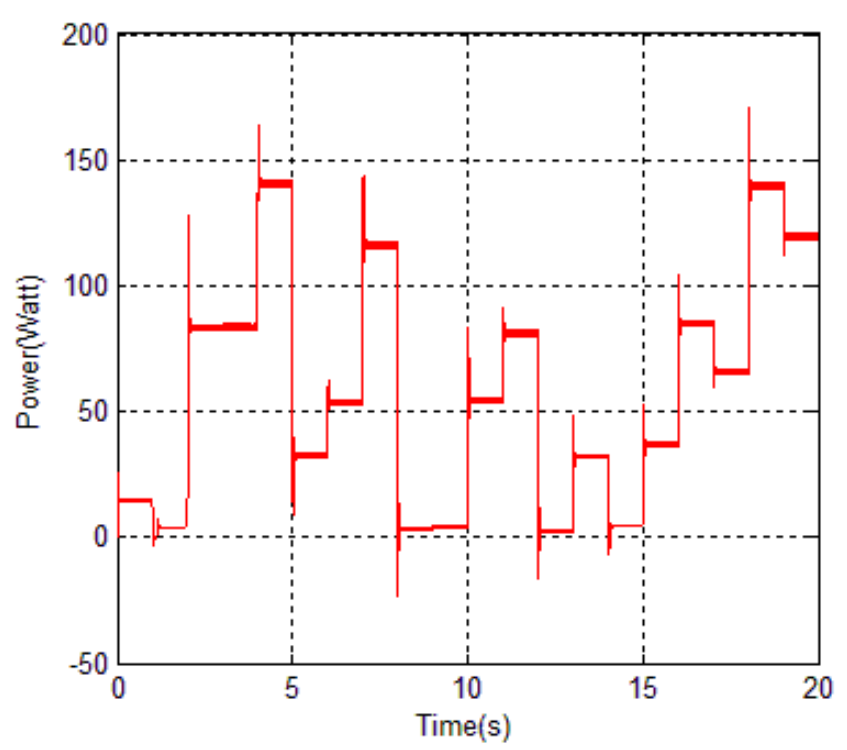

Figure 17. The output power of the generator uses MPPTFSMC with turbulent wind speed characteristics

The power coefficient graph with turbulent wind speed is shown on Figure 18 below.

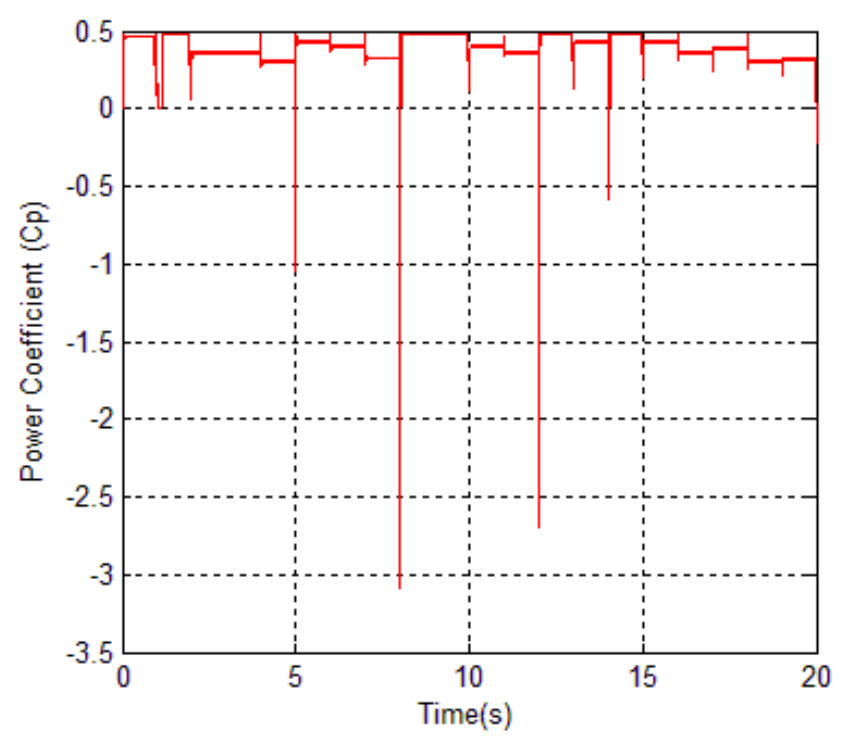

Figure 18. Power coefficient with turbulent wind speed

\section{CONCLUSION}

This study uses the MPPT-FSMC algorithm as a controller to track the maximum output power of the wind turbine generator. The generator used in this study is a Permanent Magnet Synchronous Generator (PMSG) with a maximum power capacity of 600 Watts. The combination of the sliding mode control (SMC) algorithm with fuzzy logic control (FLC) in this study was able to increase the output power of wind turbine generators 25.26 watts, 48.34 watts, 77.19 watts, 116.53 watts, and 141.07 watts respectively. wind speed $4 \mathrm{~m} / \mathrm{s}$, $5 \mathrm{~m} / \mathrm{s}, 6 \mathrm{~m} / \mathrm{s}, 7 \mathrm{~m} / \mathrm{s}$, and $8 \mathrm{~m} / \mathrm{s}$ respectively. In addition, testing the performance of the MPPT_FSMC control system was also carried out by providing a turbulent wind speed profile in the wind speed range of $2-8 \mathrm{~m} / \mathrm{s}$, and producing a stable generator output power at each speed change with an average $\mathrm{Cp}$ value of 0.43 .

\section{ACKNOWLEDGEMENT}

The authors would like to thank the Institute for Research and Community Service (DRPM ITS), Institut Teknologi Sepuluh Nopember, Surabaya. with supporting financing, the research. Also, the authors would like to thank the anonymous referees for their comments on the eelier version of this work.

\section{REFERENCES}

[1] Xia, Y., Ahmed, K.H., Williams, B.W. (2011). A new maximum power point tracking technique for permanent magnet synchronous generator based wind energy conversion system. IEEE Transaction on Power Electronic, 26(12): 3609-3620. https://doi.org/10.1109/TPEL.2011.2162251

[2] Hussain, J., Mishra, M.K. (2016). Adaptive maximum power point tracking control algorithm for wind energy conversion systems. IEEE Transaction on Energy Conversion, $31(2)$ : 697-705. https://doi.org/10.1109/TEC.2016.2520460

[3] Huang, C., Li, F., Jin, Z. (2015). Maximum power point tracking strategy for large-scale wind generation systems considering wind turbine dynamics. IEEE Transaction on Industrial Electronics, 62(4): 2530-2539. https://doi.org/10.1109/TIE.2015.2395384

[4] Kumar, D., Chatterjee, K. (2016). A review of conventional and advanced MPPT algorithms for wind energy systems. Renewable and Sustainable Energy Reviews, 55: 957-970. https://doi.org/10.1016/j.rser.2015.11.013

[5] Ferreira, M., Santos, A., Lucio, P. (2019). Short-term forecast of wind speed through mathematical models. Energy Reports, 5: 1172-1184. https://doi.org/10.1016/j.egyr.2019.05.007

[6] Xia, Y., Ahmed, K.H., Williams, B.W. (2013). Wind turbine power coefficient analysis of a new maximum power point tracking technique. IEEE Transaction on Industrial Electronics, 60(3): 1122-1132. https://doi.org/10.1109/TIE.2012.2206332

[7] Shariatpanah, H., Fadaeinedjad, R., Rashidinejad, M. (2013). A new model for PMSG-based wind turbine with yaw control. IEEE Transaction on Energy Conversion, 28(4): 929-937. https://doi.org/10.1109/TEC.2013.2281814

[8] Daili, Y., Gaubert, J.P., Rahmani, L. (2015). Implementation of a new maximum power point tracking control strategy for small wind energy conversion systems without mechanical sensors. Energy Convers. Manag., 97: 298-306. https://doi.org/10.1016/j.enconman.2015.03.062

[9] Yazıc1, İ., Yaylac1, E.K. (2019). Discrete-time integral terminal sliding mode based maximum power point controller for the PMSG-based wind energy system. IET Power Electronics, 12(14): 3688-3696. https://doi.org/10.1049/iet-pel.2019.0106

[10] Wang, J., Xu, D., Wu, B., Luo, Z. (2011). A low-cost rectifier topology for variable-speed high-power PMSG wind turbines. IEEE Transaction on Power Electronics, 26(8): 2192-2200. https://doi.org/10.1109/TPEL.2011.2106143

[11] Yenduri, K., Sensarma, P. (2016). Maximum power point tracking of variable speed wind turbines with 
flexible shaft. IEEE Transaction on Sustainable Energy, 7(3): 956-965 https://doi.org/10.1109/TSTE.2015.2510422

[12] Aubrée, R., Auger, F., Macé, M., Loron, L. (2016). Design of an efficient small wind-energy conversion system with an adaptive sensorless MPPT strategy. Renewable Energy, 86: 280-291. https://doi.org/10.1016/j.renene.2015.07.091

[13] Soliman, M.A., Hasanien, H.M., Azazi, H.Z., El-Kholy, E.E., Mahmoud, S.A. (2019). An adaptive fuzzy logic control strategy for performance enhancement of a gridconnected PMSG-Based wind turbine. IEEE Transaction Industrial and Informatics, 15(6): 3163-3173. https://doi.org/10.1109/TII.2018.2875922

[14] Beddar, A., Bouzekri, H., Babes, B., Afghoul, H. (2016). Experimental enhancement of fuzzy fractional order PI+I controller of grid connected variable speed wind energy conversion system. Energy Conversion Management, 123 : https://doi.org/10.1016/j.enconman.2016.06.070

[15] Musyafa, A., Abadi, I., Noriyati, R.D., Faiz, M.A., Asy, M.K. (2019). Design and implementation wind turbine power control system base particle swam optimization at low rate wind farm. 19(5): 149-157.

[16] Haq, I.U., Khan, Q., Khan, I., Akmeliawati, R., Nisar, K.S., Khan, I. (2020). Maximum power extraction strategy for variable speed wind turbine system via neuro-adaptive generalized global sliding mode controller. IEEE Access, 8: 1 . https://doi.org/10.1109/access.2020.2966053

[17] Maher, R.A., Abdelsalam, A.K., Dessouky, Y.G. Nouman, A. (2019). High performance state-flow based MPPT technique for micro WECS. IET Renewable Power Generation., 13(16): 3009-3021. https://doi.org/10.1049/iet-rpg.2019.0157

[18] Ma, Y., Cao, W., Yang, L., Wang, F., Tolbert, L.M. (2017). Virtual synchronous generator control of full converter wind turbines with short-term energy storage. IEEE Transaction on Industrial Electronics, 564(11): 8821-8831. https://doi.org/10.1109/TIE.2017.2694347

[19] Chen, J.H., Yau, H.T., Hung, W. (2014). Design and study on sliding mode extremum seeking control of the chaos embedded particle swarm optimization for maximum power point tracking in wind power systems. Energies, 7(3):

1706-1720 https://doi.org/10.3390/en7031706

[20] Yin, M., Xu, Y., Shen, C., Liu, J., Dong, Z.Y., Zou, Y. (2017). Turbine stability-constrained available wind power of variable speed wind turbines for active power control. IEEE Transaction on Power System, 32(3): $2487-2488$ https://doi.org/10.1109/TPWRS.2016.2605012

[21] Moradi, H., Alinejad-Beromi, Y., Yaghobi, H., Bustan, D. (2019). Sliding mode type-2 neuro-fuzzy power control of grid-connected DFIG for wind energy conversion system. IET Renewable Power Generation, 13(13): 2435-2442. https://doi.org/10.1049/ietrpg.2019.0066

[22] Bai, Y., Kou, B., Chan, C.C. (2015). A simple structure passive MPPT standalone wind turbine generator system. IEEE Transaction on Magnetics, 51(11): 0-3. https://doi.org/10.1109/TMAG.2015.2439043

[23] Musyafa, A., Pratama, D.P., Asy'ari, M.K. (2018). Design and implemented pitch angle wind turbine control system base Neuro fuzzy at East Java-Indonesia. International Journal of Mechanical and Mechatronics Engineering, 18(4): 65-72.

[24] Benbouhenni, H., Boudjema, Z., Belaidi, A. (2020). Power control of DFIG in WECS using DPC and NDPCNPWM methods. Mathematical Modelling of Engineering. $\quad$ Problem, 7(2): 223-236. https://doi.org/10.18280/mmep.070208

[25] Lertnuwat, C., Oonsivilai, A. (2017). Stability for wind turbine using observer method with permanent magnet synchronous generator (PMSG). Energy Procedia, 138: 122-127. https://doi.org/10.1016/j.egypro.2017.10.076

[26] Bedoud, K., Rhif, A., Bahi, T., Merabet, H. (2018). Study of a double fed induction generator using matrix converter: Case of wind energy conversion system. International Journal of Hydrogen Energy, 43(25): 11432-11441. https://doi.org/10.1016/j.ijhydene.2017.07.010

[27] Noriyati, R.D., Musyafa, A., Rahmadiansah, A., Utama, A.S., Asy'ari, M.K., Abdillah, M. (2020). Design and implemented buck-boost converter based fuzzy logic control on wind power plant. International Journal of Mechanical and Mechatronics Engineering, 20(1): 115122.

[28] Hui, J.C.Y., Bakhshai, A., Jain, P.K. (2016). An energy management scheme with power limit capability and an adaptive maximum power point tracking for small standalone pmsg wind energy systems. IEEE Transaction on Power Electronics, 31(7): 4861-4875. https://doi.org/10.1109/TPEL.2015.2478402

[29] Musyafa, A., Harika, A., Negara, I.M.Y., Robandi, I. (2010). Pitch angle control of variable low rated speed wind turbine using fuzzy logic controller. International Journal of Engineering and Technolpgy, 10(5): 22-25.

[30] Dehghan, S.M., Mohamadian, M., Varjani, A.Y. (2009). A new variable-speed wind energy conversion system using permanent-magnet synchronous generator and Zsource inverter. IEEE Transaction on Energy Conversion, 24(3):

714-724. https://doi.org/10.1109/TEC.2009.2016022

[31] Indriawati, K., Musyafa, A., Widjiantoro, B.L., Milatul Ummah, A. (2018). Study of supervisory control implementation in a small scale variable speed wind turbine. E3S Web Conference, 43: 1-5. https://doi.org/10.1051/e3sconf/20184301023

[32] Bracke, X. (2014). Maximum Power Point Tracking of Small Wind Turbines with a Full Active Rectifier.

[33] Naama, F.Z., Zegaoui, A., Benyessad, Y., Kessaissia, F.Z., Djahbar, A., Aillerie, M. (2019). Model and simulation of a wind turbine and its associated permanent magnet synchronous generator. Energy Procedia, 157: 737-745. https://doi.org/10.1016/j.egypro.2018.11.239

[34] Güler, N., Irmak, E., Gör, H., Kurt, E. (2017). An inverter design for a new permanent magnet synchronous generator. International Journal of Hydrogen Energy, 42(28):

17723-17732. https://doi.org/10.1016/j.ijhydene.2017.01.223

[35] Qais, M.H., Hasanien, H.M., Alghuwainem, S. (2019). Whale optimization algorithm-based Sugeno fuzzy logic controller for fault ride-through improvement of gridconnected variable speed wind generators. Engineering Application on Artificial Intelligent, 87: 103328. https://doi.org/10.1016/j.engappai.2019.103328

[36] Minh, H.Q., Frederic, N., Essounbouli, N., Abdelaziz, H. 
(2012). A new MPPT method for stand-alone wind energy conversion system. Second International Symposium of Environmental and Friendly Energies Appl, $\mathrm{pp}$ $335-340$ https://doi.org/10.1109/EFEA.2012.6294053

[37] Liu, J., Gao, Y., Luo, W., Wu, L. (2017). Takagi-Sugeno fuzzy-model-based control of three-phase AC/DC voltage source converters using adaptive sliding mode technique. IET Control Theory Application, 11(8): 12551263. https://doi.org/10.1049/iet-cta.2016.0689

[38] Dursun, E.H., Kulaksiz, A.A. (2020). Second-order sliding mode voltage-regulator for improving MPPT efficiency of PMSG-based WECS. International Journal on Electronic and Power Energy System, 121: 106149. https://doi.org/10.1016/j.ijepes.2020.106149

[39] Sharma, R., Rasmussen, T.W., Jensen, B.B. (2012). Application of a synchronous generator with a boost converter in wind turbines: An experimental overview. IET Renewable on Power Generation, 6(6): 414-423. https://doi.org/10.1049/iet-rpg.2011.0210

[40] Utkin, V. (2013). Sliding mode control of DC/DC converters. Journal of The Franklin Institute, 350(8): 2146-2165. https://doi.org/10.1016/j.jfranklin.2013.02.026

[41] Zhao, Y., Wei, C., Zhang, Z., Qiao, W. (2013). A review on position/speed sensorless control for permanentmagnet synchronous machine-based wind energy conversion systems. in IEEE Journal of Emerging and
Selected Topics in Power Electronics, 1(4): 203-216. https://doi.org/10.1109/JESTPE.2013.2280572

[42] Chen, Z., Guerrero, J.M., Blaabjerg, F. (2009). A review of the state of the art of power electronics for wind turbines. IEEE Transaction on Power Electronics, 24(8): 1859-1875. https://doi.org/10.1109/TPEL.2009.2017082

[43] Miqoi, S., El Ougli, A., Boutouba, M., Tidhaf, B. (2017). Fuzzy sliding mode control for maximum power point tracking of a photovoltaic pumping system. Journal of Electronical System, 13(1): 95-114.

\section{NOMENCLATURE}

PMSG Permanent Magnet Synchronous Generator

SMC Sliding Mode Control

FSMC Fuzzy Sliding Mode Control

MPPT Maximum Power Point Tracking

WECS Wind Energy Conversion System

$\mathrm{Cp}$

EIA

VSWT

FSWT

MSC

$\beta$

$\lambda$

$\omega_{\mathrm{m}}$

$\psi_{\mathrm{pm}}$
Power Coefficient

Energy Information Administration

Variable Speed Wind Turbine

Fix Speed Wind Turbine

Machine Side Converter

Pitch Angle (degree)

Tip Speed Ratio (TSR)

Wind Turbine Angular Speed

Permanent Magnet Flux 